\title{
LITERASI NUMERASI SISWA DALAM PEMECAHAN MASALAH TIDAK TERSTRUKTUR
}

\author{
Muhammad Rifqi Mahmud ${ }^{1}$, Inne Marthyane Pratiwi $^{2}$ \\ ${ }^{1}$ Universitas Islam Negeri Sunan Gunung Djati Bandung \\ m.rifqi.mahmud@uinsgd.ac.id \\ ${ }^{2}$ Universitas Islam Negeri Sunan Gunung Djati Bandung \\ inne.mp@uinsgd.ac.id
}

\begin{abstract}
ABSTRAK
Penelitian ini bertujuan untuk mengeksplorasi literasi numerasi siswa dalam pemecahan masalah tidak terstruktur pada materi bilangan. Partisipan dalam penelitian ini adalah 34 siswa kelas IV di salah satu sekolah di Kota Bandung. Pendekatan penelitian yang digunakan adalah kualitatif dengan metode studi kasus. Jenis data yang dikumpulkan yaitu hasil tes soal pemecahan masalah tidak terstruktur. Teknik pengumpulan data dengan menggunakan tes, analisis dokumen, dan wawancara. Teknik analisis data menggunakan thematic analysis, sedangkan validitas data menggunakan triangulasi, member checking, dan refleksivitas. Hasil penelitian menunjukkan bahwa literasi numerasi siswa dalam pemecahan masalah tidak terstruktur yaitu siswa mampu memecahkan masalah tidak terstruktur dalam konteks kehidupan sehari-hari; siswa mampu menganalisis informasi yang diperoleh dari soal kemudian menggunakan interpretasi analisis untuk memprediksi dan mengambil kesimpulan. Adapun kesulitan yang dialami siswa yaitu kesulitan memahami soal; kurangnya pemahaman siswa pada materi prasyarat; kesulitan membangun strategi penyelesaian; dan kesulitan dalam mengambil kesimpulan.
\end{abstract}

Kata Kunci: literasi numerasi, pemecahan masalah, masalah tidak terstruktur.

\begin{abstract}
This study aims to explore the numeracy literacy of students in ill-structured problem-solving on the matter of numbers. This study involved 34 students of the $4^{\text {th }}$ grader in one Madrasah Ibtidaiyah in Bandung. The research approach used is qualitative with the case study method. The type of data collected is test results about ill structured problem-solving. The data were collected from tests, document analysis, and interviews. After that, the data were analysed using thematic analysis, while the validity of data using triangulation, member checking, and reflexivity. The results of the research showthat students' numeracy literacy in ill structured problem-solving are (1) students are able to solve ill structured problem in the context of daily life; (2) students are able to analyze the information obtained from the problem then use the interpretation analysis to predict and draw conclusions. The difficulties experienced by students are (1) the difficulty in understanding the problem; (2) lack of students' understanding of the prerequisite material; (3) the difficulty in developing a settlement strategy; and (4) the difficulty in drawing conclusions.
\end{abstract}

Keywords: numeracy literacy, problem solving, ill-structured problem. 
Format Sitasi: Mahmud, M. F. \& Pratiwi, I. M. (2019). Literasi Numerasi Siswa dalam Pemecahan Masalah Tidak Terstruktur. KALAMATIKA Jurnal Pendidikan Matematika, 4(1), 69-88.

Penyerahan Naskah: 25 Maret 2019 || Revisi: 2 Mei 2019 || Diterima: 3 Mei 2019

\section{PENDAHULUAN}

Keterampilan numerasi dibutuhkan dalam semua aspek kehidupan, baik di rumah maupun di masyarakat. Dalam kehidupan sehari-hari dan bermasyarakat, misalnya ketika berbelanja, merencanakan liburan, memulai usaha, membangun rumah, informasi mengenai kesehatan, semuanya membutuhkan numerasi. Informasi-informasi tersebut biasanya dinyatakan dalam bentuk numerik atau grafik. Untuk membuat keputusan yang tepat, siswa harus memahami numerasi. Numerasi adalah kemampuan, kepercayaan diri dan kesediaan untuk terlibat dengan informasi kuantitatif atau spasial untuk membuat keputusan berdasarkan informasi dalam semua aspek kehidupan sehari-hari (Alberta, 2018).

Literasi numerasi adalah pengetahuan dan kecakapan untuk menggunakan berbagai macam angka dan simbol terkait dengan matematika dasar untuk memecahkan masalah praktis dalam kehidupan sehari-hari lalu menganalisis informasi yang ditampilkan dalam berbagai bentuk serta menginterpretasi hasil analisis untuk memprediksi dan mengambil keputusan (Kemdikbud, 2017). Secara sederhana, numerasi dapat diartikan sebagai kemampuan untuk mengaplikasikan konsep bilangan dan keterampilan operasi hitung di dalam kehidupan seharihari (misalnya, di rumah, pekerjaan, dan partisipasi dalam kehidupan masyarakat dan sebagai warga negara) dan kemampuan untuk menginterpretasi informasi kuantitatif yang terdapat di sekeliling kita. Kemampuan ini ditunjukkan dengan kenyamanan terhadap bilangan dan cakap menggunakan keterampilan matematika secara praktis untuk memenuhi tuntutan kehidupan. Kemampuan ini juga merujuk pada apresiasi dan pemahaman informasi yang dinyatakan secara matematis, misalnya grafik, bagan, dan tabel.

Perkembangan literasi dan numerasi saling berkaitan (Purpura et al., 2011). Anak-anak yang berusaha dalam satu domain sering mengalami kesulitan dalam domain lain (Light \& Defries, 1995). Pengembangan keterampilan literasi dan numerasi secara bersamaan adalah cara yang yang dapat dilakukan di sekolah formal (Munn, 1994). Pengembangan literasi dan numerasi dapat diamati dalam konteks pengalaman belajar di seluruh mata pelajaran. Guru tidak diharuskan untuk secara formal mengevaluasi dan melaporkan perkembangan secara 
terpisah dari hasil pembelajaran. Perkembangan literasi dan numerasi tidak dimaksudkan sebagai alat diagnostik formal. Literasi numerasi dapat digunakan oleh guru untuk menginformasikan pemilihan strategi penilaian, kegiatan, dan alat yang sesuai untuk siswa mereka.

Literasi numerasi terdiri dari tiga aspek berupa berhitung, relasi numerasi, dan operasi aritmatika (Purpura, 2009). Berhitung adalah kemampuan untuk menghitung suatu benda secara verbal dan kemampuan untuk mengidentifikasi jumlah dari benda. Relasi numerasi berkaitan dengan kemampuan untuk membedakan kuantitas suatu benda seperti lebih banyak, lebih sedikit, lebih tinggi, atau lebih pendek. Sementara itu, operasi aritmatika adalah kemampuan untuk mengerjakan operasi matematika dasar berupa penjumlahan dan pengurangan. Tiga aspek literasi numerasi yang telah dijelaskan sebelumnya merupakan aspek dasar dalam pembelajaran matematika yang penting diperkenalkan sejak usia dini hingga anak memasuki kelas rendah (Jordan, dkk., 2009).

Kemampuan numerasi anak dapat diketahui melalui tahap perkembangan numerasi, yaitu informal numerasi, pengetahuan numerasi, dan numerasi formal (Purpura, Baroody \& Lonigan, 2013). Pada tahap informal numerasi, anak sudah mampu membilang secara runtut dan mengenal kualitas benda. Informal numerasi terjadi pada anak usia dini hingga sekolah dasar awal. Memasuki usia awal sekolah dasar, kemampuan numerasi siswa berubah menuju tahap pengetahuan numerasi. Kemampuan numerasi berkembang ke arah konsep abstrak (Sarama \& Clements, 2009). Siswa belajar menggunakan simbol-simbol dan bahasa matematika di pendidikan formal. Pada tahap numerasi formal, siswa mempelajari operasi matematika yang lebih rumit karena penggunaan operasi aritmatika menyajikan permasalahan matematika yang tidak hanya diaplikasikan dalam kehidupan sehari-hari. Anak-anak akan belajar mengoperasikan aritmatika dasar seperti penjumlahan, pengurangan, perkalian, dan pembagian. Agar siswa lebih memahami konsep penggunaan operasi aritmatika maka guru mengintegrasikan operasi aritmatika dasar ke dalam bentuk soal cerita.

Kemampuan numerasi anak akan memengaruhi learning trajectory nya. Clements \& Sarama (2004) memberikan pengertian mengenai learning trajectory yaitu gambaran pemikiran siswa pada saat proses pembelajaran berupa dugaan dan hipotesis dari serangkaian desain pembelajaran untuk mendorong perkembangan berpikir siswa agar tujuan pembelajaran 
matematika sesuai dengan tujuan yang diharapkan. Learning trajectory dapat dibedakan menjadi dua jenis yaitu learning trajectory fungsional dan learning trajectory struktural.

Numerasi mencakup keterampilan mengaplikasikan konsep dan kaidah matematika dalam situasi real sehari-hari, saat permasalahannya sering kali tidak terstruktur (illstructured), memiliki banyak cara penyelesaian, atau bahkan tidak ada penyelesaian yang tuntas, serta berhubungan dengan faktor nonmatematis. Masalah ill-structured biasanya berada pada konteks kehidupan nyata daripada soal-soal biasanya. Hal ini berarti bahwa proses pemecahan masalah tidak terstruktur membutuhkan pengetahuan dari domain tertentu. Kendala yang muncul biasanya melibatkan masalah sosial, ekonomi, atau isu-isu yang dapat diselesaikan melalui cara interpretasi dan negosiasi (Goel, 1992). Selanjutnya, kemampuan pemecahan masalah tidak terstruktur mempunyai penyelesaian yang berbeda dari kemampuan pemecahan masalah terstruktur (Toy, 2007).

Literasi numerasi merupakan bagian dari matematika, dalam hal komponen literasi numerasi diambil dari cakupan matematika di dalam kurikulum 2013. Salah satu cakupan matematika dalam kurikulum 2013 adalah bilangan. Komponen literasi yang dimaksud yaitu mengestimasi dan menghitung dengan bilangan bulat (Kemdikbud, 2017). Kenyataan yang terjadi pada siswa yaitu seringkali siswa tidak dapat menerapkan pengetahuan matematika mereka di bidang lain secara langsung menunjukkan adanya suatu kebutuhan bahwa semua guru perlu memfasilitasi proses tesebut.

Bertitik tolak dari hal tesebut, maka peneliti mencoba melakukan penelitian mengenai analisis literasi numerasi siswa di Madrasah Ibtidaiyah. Analisis kemampuan literasi numerasi di kelas empat sekolah dasar dilakukan mengingat belum ada yang melaksanakan penelitian ini. Oleh sebab itu, peneliti akan mengadakan penelitian dengan tujuan untuk mengeksplorasi literasi numerasi siswa dalam pemecahan masalah tidak terstruktur pada materi bilangan.

\section{METODE PENELITIAN}

Jenis penelitian ini adalah penelitian dengan pendekatan kualitatif. Penelitian kualitatif adalah penelitian untuk memahami fenomena tentang apa yang dialami oleh subjek penelitian dengan cara deskripsi dalam bentuk kata-kata dan bahasa berdasarkan hasil pengamatan (Margono, 2014). Sementara itu, metode yang digunakan adalah studi kasus. Metode studi kasus dipilih agar dapat menjawab pertanyaan penelitian yang diajukan yaitu untuk 
mengeksplorasi literasi numerasi siswa dalam pemecahan masalah tidak terstruktur pada materi bilangan.

Penelitian dilaksanakan di salah satu Madrasah Ibtidaiyah di kota Bandung. Partisipan dari penelitian ini ialah siswa kelas IV sebanyak 34 orang. Dalam penelitian ini, peneliti tidak melakukan tindakan untuk membuktikan suatu strategi atau metode pembelajaran. Namun, peneliti melakukan tes, menganalisis dokumen untuk mengetahui kemampuan literasi numerasi siswa dalam pemecahan masalah tidak terstruktur pada materi bilangan, dan wawancara.

Teknik pengumpulan data yang pertama yaitu tes yang digunakan untuk menganalisis kemampuan literasi numerasi siswa dengan melihat strategi penyelesaian masalah tidak terstruktur pada materi bilangan. Teknik pengumpulan data yang kedua yaitu analisis dokumen. Dokumen yang dianalisis yaitu hasil tes siswa. Melalui dokumen, peneliti dapat menganalisis strategi penyelesaian masalah tidak terstruktur pada materi bilangan yang dikerjakan siswa. Teknik pengumpulan data yang ketiga adalah wawancara. Wawancara dilakukan secara informal untuk mengetahui teknik penyelesaian masalah tidak struktur pada materi bilangan yang dilakukan oleh siswa. Wawancara informal merupakan wawancara yang dilakukan secara wajar seperti perbincangan sehari-hari secara santai dan cair dalam konteks alamiah (Putra \& Dwilestari, 2012).

Analisis data dalam penelitian ini menggunakan pendekatan kualitatif dengan teknik thematic analysis atau analisis tematik. Naughton dan Hughes (2009) menyatakan bahwa analisis tematik merupakan teknik analisis data yang dilakukan dengan cara melihat dan menemukan tema-tema dan kategori yang diperoleh dalam data yang telah dikodekan terlebih dahulu. Tahapan analisis data dalam penelitian ini yaitu: (1) menyiapkan data mentah; (2) membaca keseluruhan data; (3) coding data; (4) menghubungkan hasil coding; (5) menginterpretasi hasil coding (Creswell, 2013). Validitas data dalam penelitian kualitatif adalah kegiatan untuk menilai keakuratan suatu temuan yang telah dideskripsikan oleh peneliti berdasarkan hasil pengumpulan data (Creswell, 2014). Validitas data dalam penelitian ini menggunakan triangulasi, member checking, dan refleksivitas. 


\section{HASIL DAN PEMBAHASAN}

\section{Hasil}

Berdasarkan tes yang sudah dilakukan, tidak semua soal dianalisis, hanya tiga soal saja yang mewakili beberapa learning trajectory siswa. Learning trajectory ini dipengaruhi oleh literasi numerasi siswa. Berikut merupakan jawaban hasil tes literasi numerasi siswa dalam pemecahan masalah tidak terstruktur materi bilangan.

Soal No. 1

Soal nomor 1 meminta siswa untuk mengestimasi jagung Pak Basri dapat habis dalam seminggu jika Pak Basri memiliki 1.063 jagung kering dan terjual sebanyak 100 buah tiap harinya. Dari hasil tes diperoleh jawaban sebagai berikut.

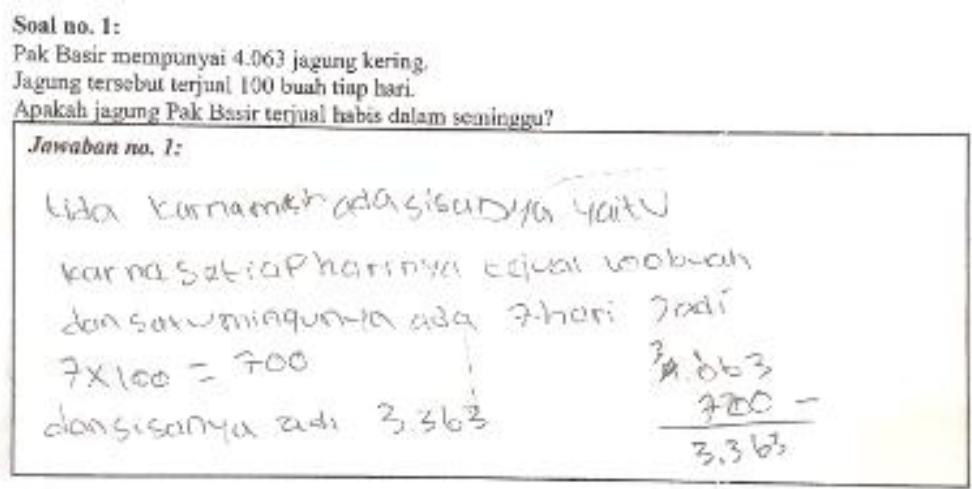

Gambar 1. Jawaban Tipe A Nomor 1

Gambar 1 merupakan salah satu jawaban yang tepat. Siswa menjawab dengan cara menghitung banyaknya jagung yang terjual dalam satu minggu, $7 \times 100=700$. Bilangan 7 diperoleh dari banyaknya hari dalam seminggu. Kemudian siswa mengestimasikan bahwa akan ada jagung yang bersisa jika dijual dalam waktu satu minggu. Untuk memperoleh jawaban tersebut, siswa melakukan operasi hitung pengurangan yaitu $4.063-700=3.363$ jagung, sehingga diperoleh kesimpulan bahwa jagung tidak habis terjual dalam seminggu. Terdapat tujuh siswa yang menjawab benar. 


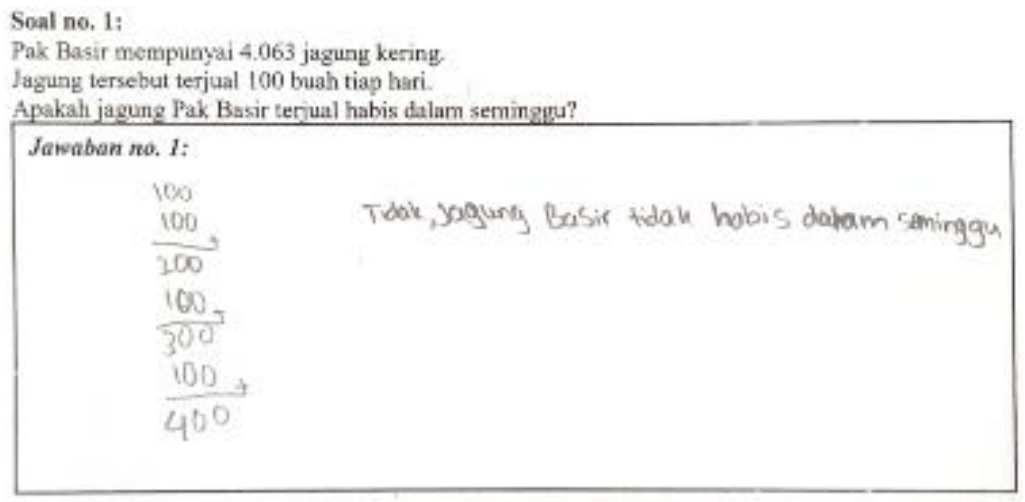

Gambar 2. Jawaban Tipe B Nomor 1

Gambar 2 menunjukkan bahwa kemampuan estimasi siswa lebih baik lagi. Siswa mengetahui bahwa banyaknya hari dalam seminggu yaitu tujuh. Strategi yang dilakukan siswa yaitu menjumlahkan jagung yang terjual dari hari ke hari, namun berhenti pada hari keempat dengan jumlah 400. Berdasarkan hasil wawancara dengan siswa, diperoleh gambaran bahwa siswa sudah mampu mengestimasi jika dalam tujuh hari hanya akan terjual 700 saja, sehingga jagung tidak akan habis terjual dalam seminggu. Terdapat dua orang siswa yang menjawab dengan strategi tersebut.

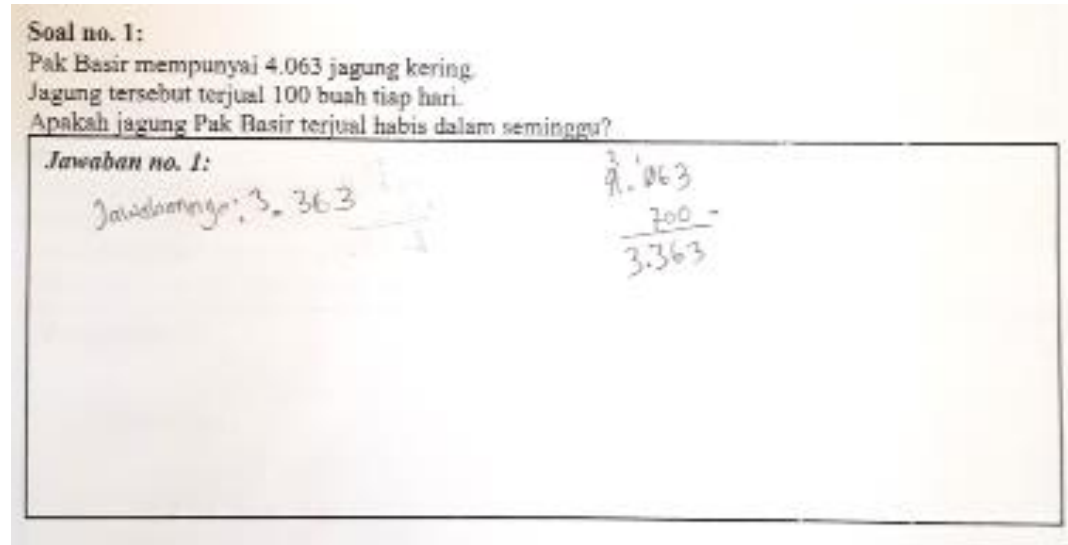

Gambar 3. Jawaban Tipe C Nomor 1

Gambar 3 merupakan salah satu pekerjaan siswa yang melakukan operasi hitung dengan tepat, namun siswa lupa menjawab pertanyaan yang tertera pada soal. Siswa tidak menyimpulkan jagung pak Basri tidak habis terjual dalam seminggu. Kesalahan tersebut dilakukan oleh dua orang siswa. 


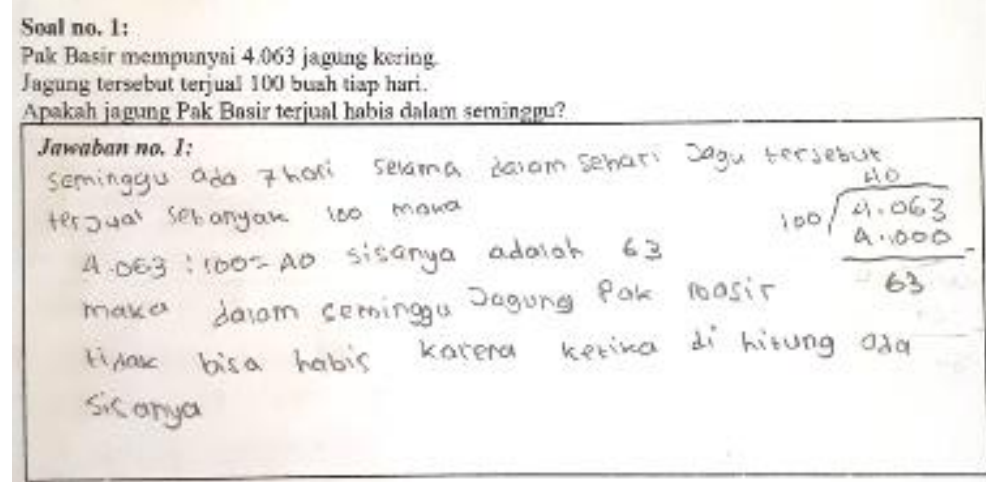

Gambar 4. Jawaban Tipe D Nomor 1

Strategi membagi banyaknya seluruh jagung yaitu 4.063 buah dengan banyaknya jagung yang terjual setiap hari yaitu 100 buah dilakukan oleh beberapa siswa seperti yang terlihat pada Gambar 4. Kekeliruan terjadi pada siswa dalam menyimpulkan hasil jawabannya. Siswa seharusnya menjawab jagung akan habis terjual pada hari ke-40, bukan sisa jagung yang diperoleh dari sisa operasi hitung pembagian.

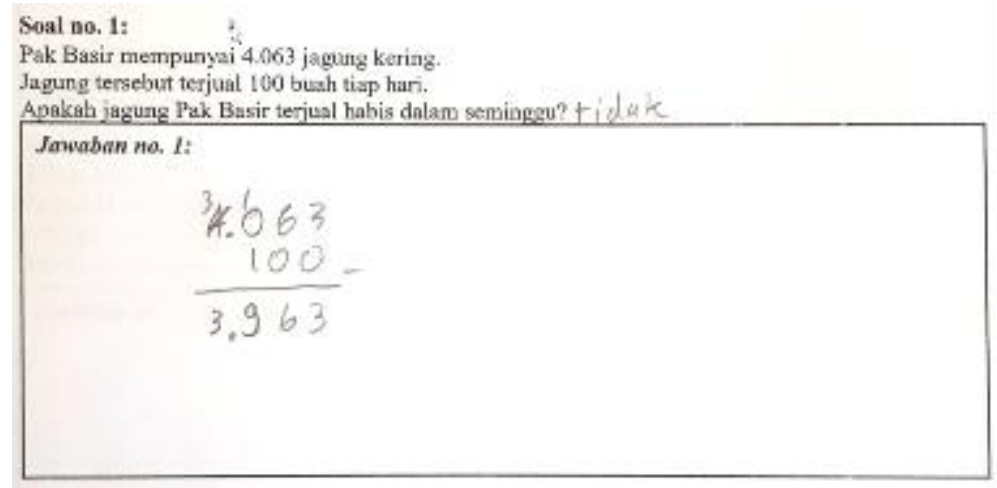

Gambar 5. Jawaban Tipe E Nomor 1

Gambar 5 merupakan jawaban dari pekerjaan siswa yang kurang tepat. Strategi yang dilakukan oleh siswa yaitu mengurangkan bilangan 4.063 dengan 100 sehingga diperoleh jawaban 3.963. Dalam hal ini, siswa belum memahami konsep waktu, bahwa terdapat tujuh hari dalam seminggu.

Soal No. 2

Soal nomor 2 digunakan untuk mengetahui linerasi numerasi pada konsep pembagian bilangan bulat dengan bilangan bulat lainnya. Ketika bilangan yang pertama tidak habis dibagi, maka akan ada sisa. Biasanya siswa diajarkan untuk menuliskan hasil bagi dengan sisa, lalu mereka juga belajar menyatakan hasil bagi dalam bentuk desimal. Siswa diminta untuk 
menghitung banyaknya minibus yang dibutuhkan untuk mengangkut 40 anak jika masingmasing minibus dapat terdiri dari 12 tempat duduk. Dari hasil tes, diperoleh hasil sebagai berikut.

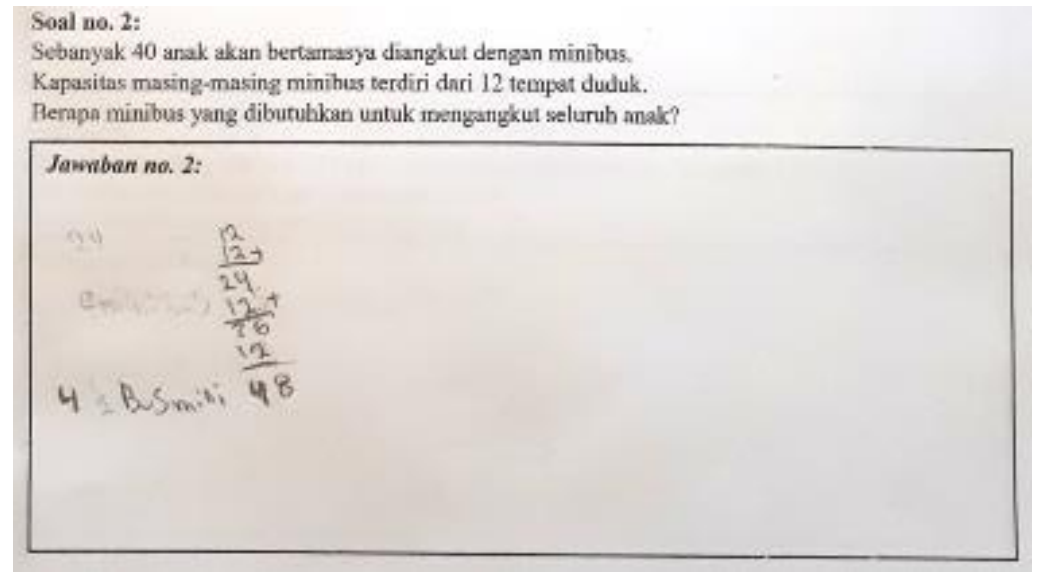

Gambar 6. Jawaban Tipe A Nomor 2

Gambar 6 merupakan salah satu strategi yang dilakukan oleh tujuh orang siswa. Strategi yang dilakukan adalah dengan menjumlahkan banyaknya tempat duduk pada minibus pertama dengan minibus kedua sehingga diperoleh 24. Kemudian siswa menambahkan 12 tempat duduk lagi sehingga diperoleh 36. Selanjutnya siswa menambahkan 12 tempat duduk lagi sehingga diperoleh 48. Berdasarkan hasil wawancara, setelah memperoleh 48, siswa dapat menyimpulkan bahwa minibus yang dibutuhkan adalah sebanyak empat minibus. Hal tersebut diperoleh dari banyaknya penjumlahan 12 sehingga mendapatkan hasil 48.

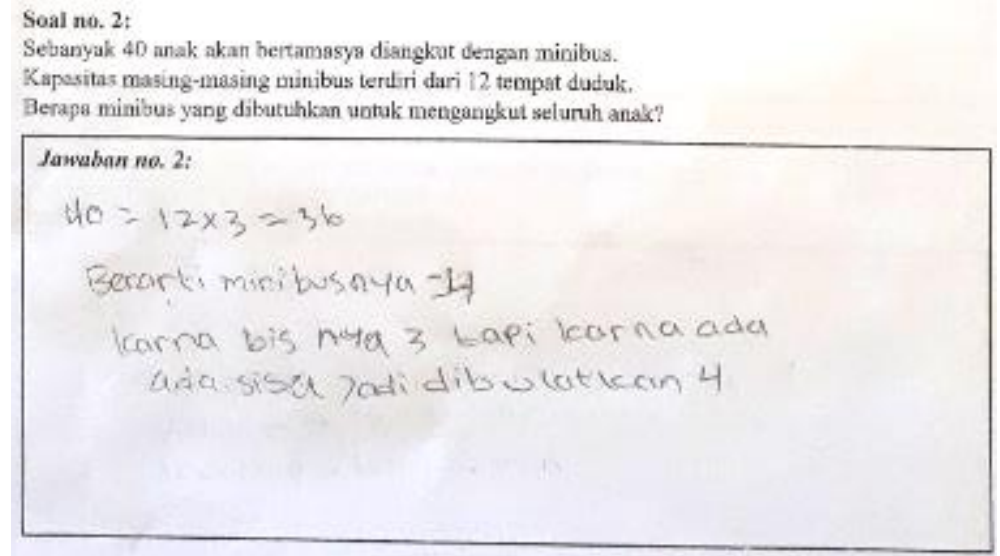

Gambar 7. Jawaban Tipe B Nomor 2

Gambar 7 merupakan strategi yang hampir serupa dengan strategi siswa pada Gambar 6. Siswa mengalikan banyaknya tempat duduk dengan bilangan 3 yang merupakan banyaknya 
minibus. Berdasarkan hal tersebut diperoleh jawaban 36. Jika terdapat tiga minibus, maka hanya 36 anak yang dapat diangkut. Hal ini berarti tidak semua anak dapat terangkut oleh minibus dan membutuhkan minibus tambahan.

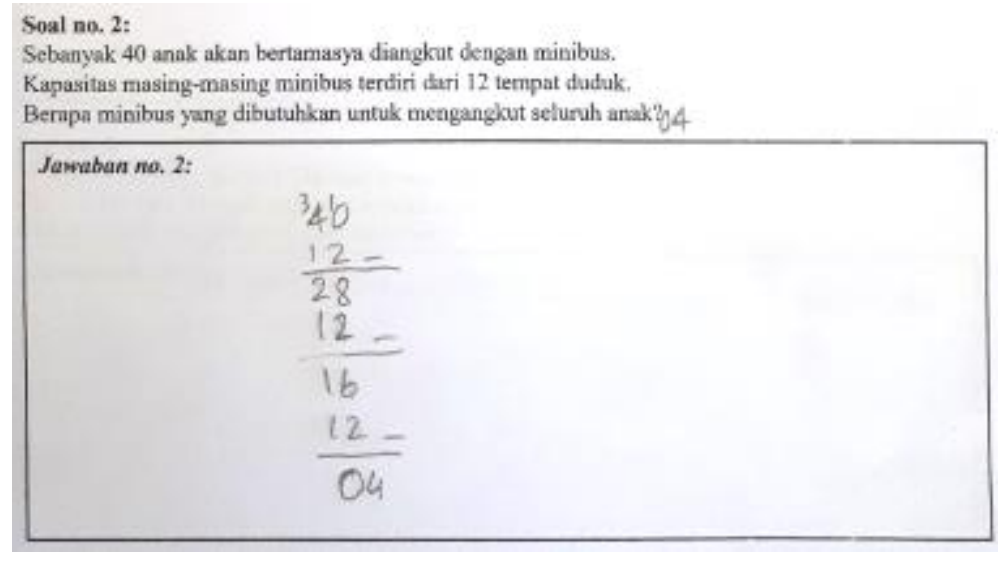

Gambar 8 Jawaban Tipe C Nomor 2

Gambar 8 merupakan kebalikan dari Gambar 6, siswa mengerjakan dengan strategi mengurangkan 40 dengan 12 secara berulang. Setelah tiga kali melakukan pengurangan berulang, masih terdapat sisa anak yang belum masuk minibus. Berdasarkan hal tersebut, siswa menyimpulkan kebutuhan minibus adalah sebanyak empat buah.

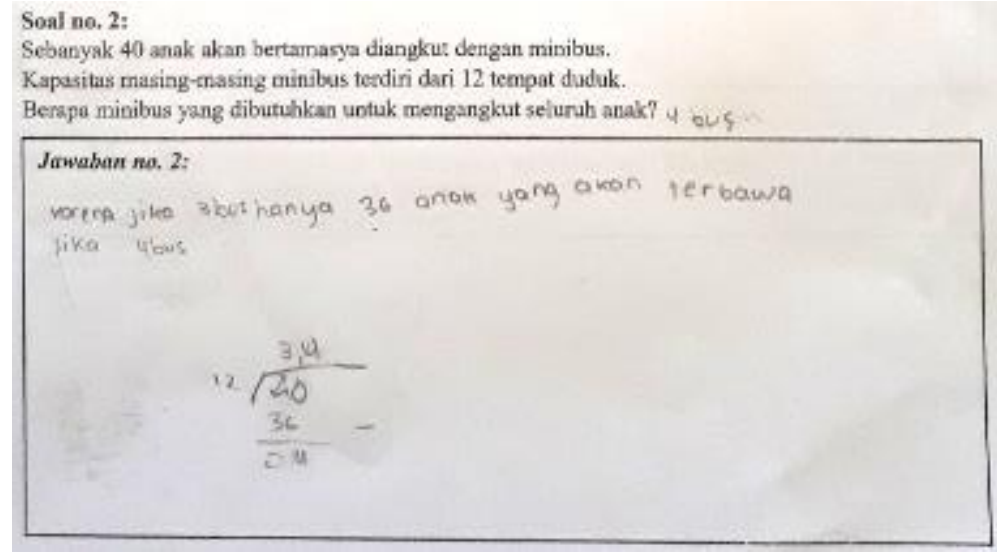

Gambar 9. Jawaban Tipe D Nomor 2

Berdasarkan Gambar 9, strategi yang digunakan siswa adalah membagi banyak siswa dengan banyaknya tempat duduk. Hasil yang diperoleh adalah 3,4. Secara matematis, kaidah pembulatan ke bawah dilakukan dan diperoleh hasil 3 minibus. Namun, apabila pembulatan ke bawah, maka terdapat anak yang tidak terangkut oleh minibus. Oleh karena itu, siswa tersebut melakukan pembulatan ke atas, banyaknya minibus yang dibutuhkan adalah 4 buah. Strategi pada Gambar 9 hanya dilakukan oleh satu orang siswa. 


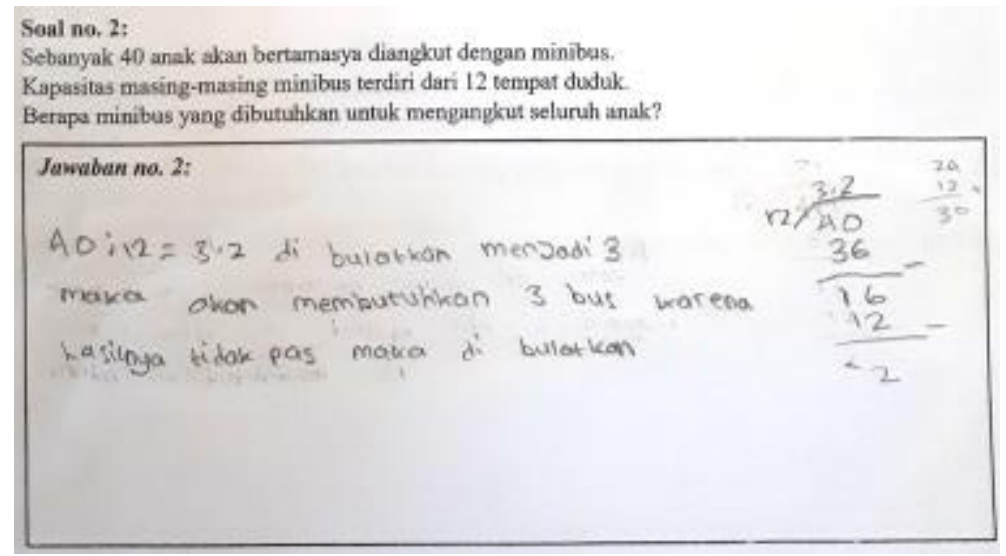

Gambar 10. Jawaban Tipe E Nomor 2

Strategi membagi banyaknya siswa dengan banyaknya tempat duduk juga dilakukan oleh seorang siswa seperti terlihat pada Gambar 10. Kesalahan terletak pada hasil pembagian dan pembulatan. Berdasarkan hasil perhitungan siswa, diperoleh jawaban 3,2. Selanjutnya, siswa membulatkan 3,2 dengan kaidah pembulatan ke bawah, sehingga diperoleh jawaban 3 bus yang dibutuhkan untuk mengangkut seluruh anak.

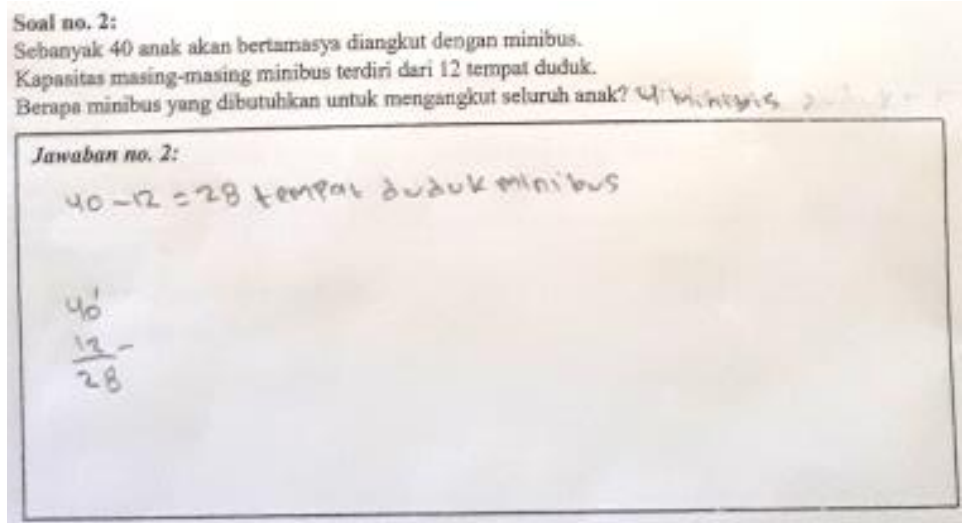

(a)

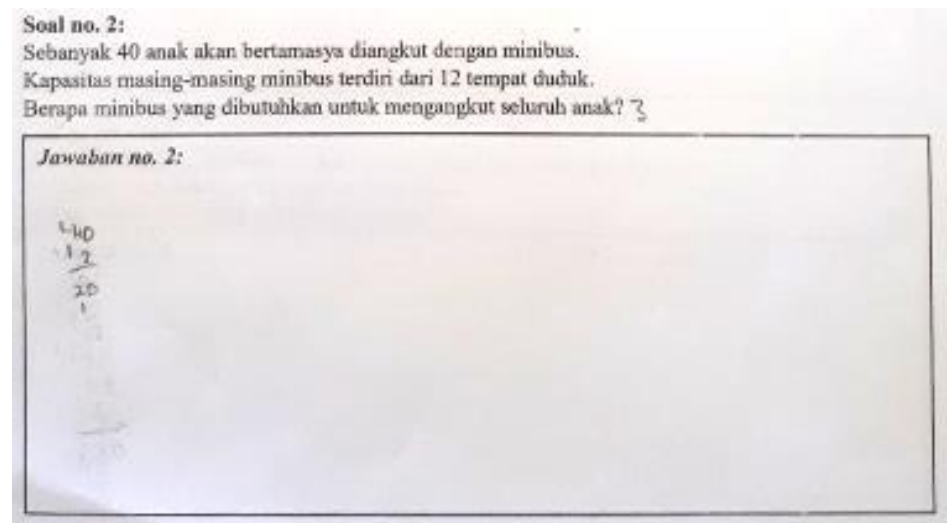

(b)

Gambar 11 (a) dan (b) Jawaban Tipe F Nomor 2 
Strategi yang dilakukan oleh siswa berdasarkan Gambar 11 adalah dengan mengurangkan 40 anak dengan banyaknya tempat duduk. Gambar 11 (a) menunjukkan hasil yang tepat jika 40 dikurangi 12. Sedangkan Gambar 11 (b) menunjukkan hasil yang kurang tepat jika 40 dikurangi 12. Namun, kedua pekerjaan tersebut tidak tepat dilakukan oleh siswa. Artinya, siswa belum memhami betul maksud dari soal.

\section{Soal No. 4}

Pada soal nomor 4 siswa diminta untuk menghitung potongan bambu yang dipotong menjadi tiga bagian. Panjang bambu seluruhnya adalah $408 \mathrm{~cm}$. Potongan pertama adalah 128 $\mathrm{cm}$. Maka, sisa bambu yang belum dipotong yaitu $280 \mathrm{~cm}$. Karena potongan kedua dan ketiga sama panjang, maka bambu dibagi dua bagian sama panjang, artinya 280 dibagi 2 diperoleh jawaban $140 \mathrm{~cm}$. Berikut pemaparan jawaban hasil tes beberapa siswa.

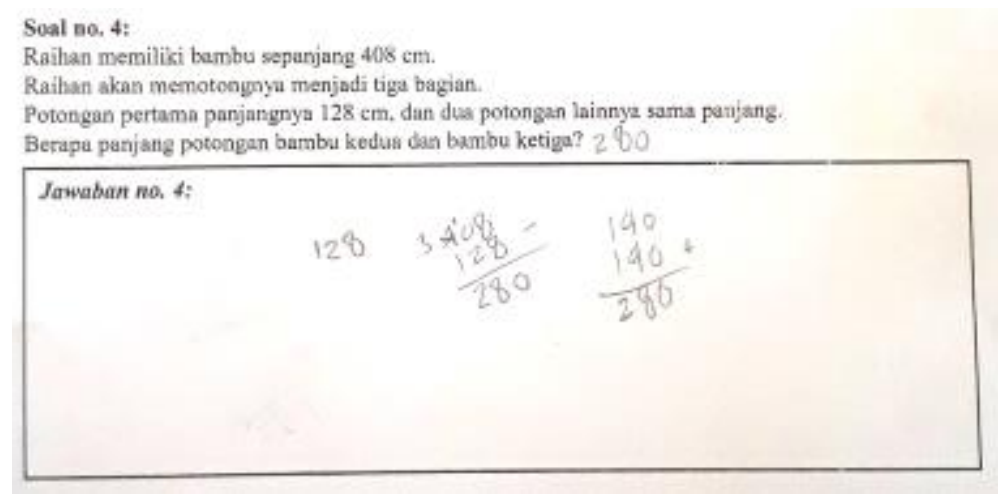

Gambar 12. Jawaban Tipe A Nomor 4

Gambar 12 menunjukkan pekerjaan dengan jawaban akhir yang tepat. Siswa mengurangkan $408 \mathrm{~cm}$ dengan $128 \mathrm{~cm}$, diperoleh jawaban $280 \mathrm{~cm}$. Selanjutnya siswa melakukan estimasi penjumlahan dua bilangan yang sama sehingga menghasilkan $280 \mathrm{~cm}$. Dengan demikian diperoleh jawaban $140 \mathrm{~cm}$.

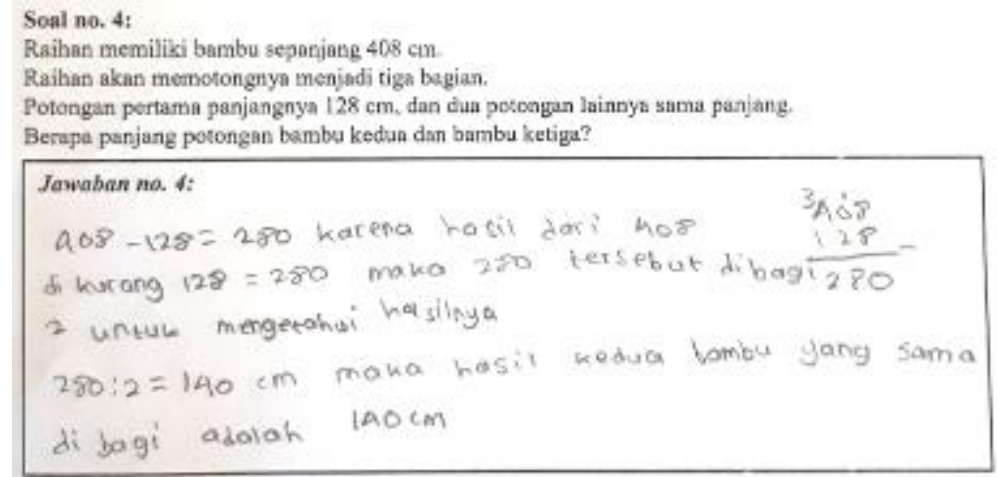

Gambar 13. Jawaban Tipe B Nomor 4 
Gambar 13 menunjukkan pekerjaan siswa dengan jawaban yang tepat. Siswa melakukan operasi hitung pengurangan 408 dengan 128 sehingga diperoleh jawaban $280 \mathrm{~cm}$. Learning trajectory siswa sudah sampai pada pemahaman apabila bambu dipotong dua bagian sama panjang, maka masing-masing bambu panjangnya diperoleh dengan cara membagi dua panjang mula-mula. Berdasarkan hal tersebut, maka diperoleh jawaban $140 \mathrm{~cm}$.

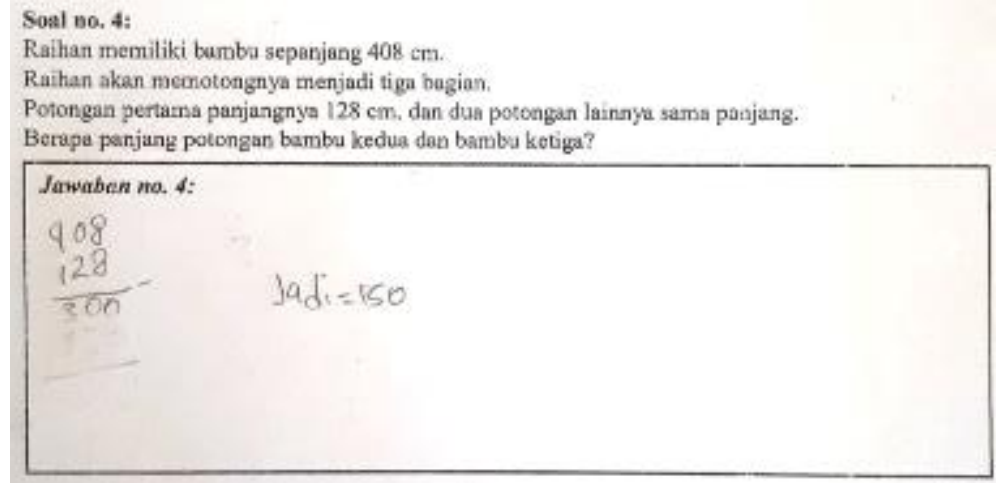

(a)

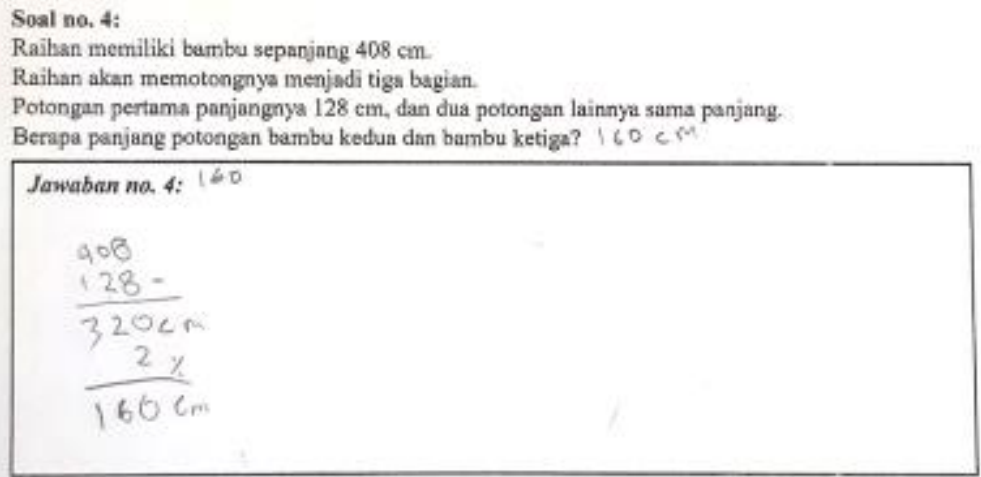

(b)

Gambar 14 (a) dan (b). Jawaban Tipe C Nomor 4

Gambar 14 (a) dan (b) merupakan jawaban pekerjaan siswa yang kurang tepat. Strategi yang digunakan sama seperti pada Gambar 13, namun siswa kurang teliti dalam melakukan operasi hitung pengurangan. Pada Gambar 14 (a) diperoleh hasil pengurangan $300 \mathrm{~cm}$, kemudian siswa membagi dua $300 \mathrm{~cm}$ sehingga diperoleh hasil 150. Pada Gambar 14 (b) diperoleh hasil $320 \mathrm{~cm}$, selanjutnya siswa membagi dua $320 \mathrm{~cm}$ sehingga diperoleh hasil 160 $\mathrm{cm}$. Berdasarkan hasil wawancara dengan siswa, siswa mengaku bahwa siswa tidak teliti dalam melakukan operasi hitung pengurangan. 
Sual ne, 4:

Rathan memiliki bambo sepanjang $408 \mathrm{~cm}$

Rnihan akan memotongrya menjadi tiga bagian.

Potongan pertama panjangnya $128 \mathrm{~cm}$. dan dua potongan lainnya sama panjäng.

Berapa panjung potongan bumbu kedus dan bambu ketiga?

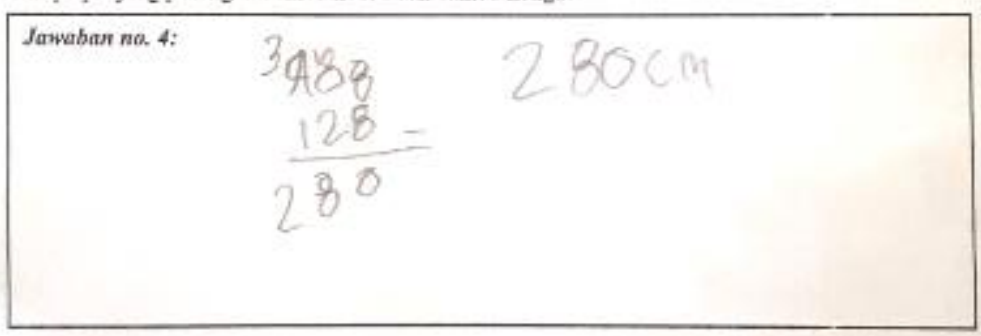

Gambar 15. Jawaban Tipe C Nomor 4

Gambar 15 merupakan hasil pekerjaan siswa yang kurang tepat. Siswa sudah paham bahwa bambu berikutnya merupakan sisa dari bambu yang sudah dipotong. Siswa mengurangkan $408 \mathrm{~cm}$ dengan $128 \mathrm{~cm}$, sehingga diperoleh $280 \mathrm{~cm}$. Namun, pekerjaan siswa belum selesai, sehingga didapatkan hasil akhir $280 \mathrm{~cm}$.

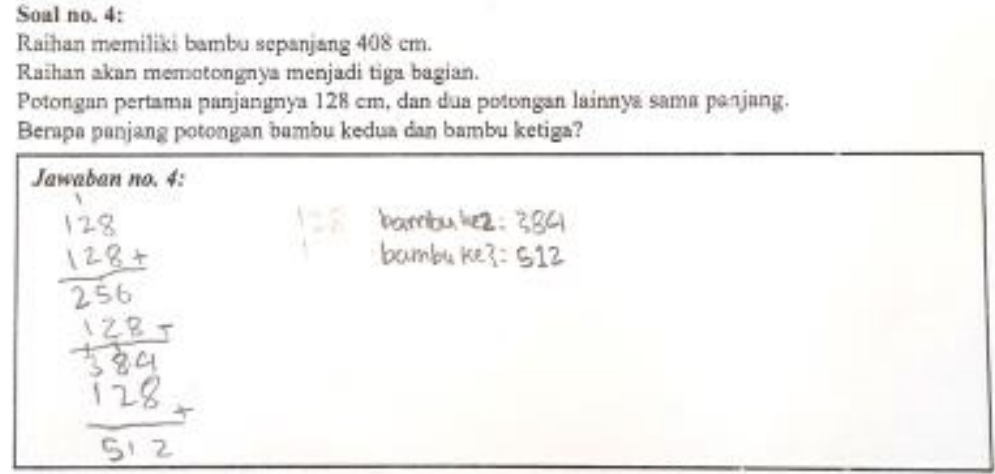

Gambar 16. Jawaban Tipe D Nomor 4

Berdasarkan Gambar 16, pekerjaan siswa kurang tepat. Siswa memperoleh panjang potongan bambu kedua dengan menjumlahkan panjang bambu pertama yakni $128 \mathrm{~cm}$ sebanyak tiga kali, diperoleh jawaban $384 \mathrm{~cm}$. Selanjutnya potongan bambu ketiga diperoleh dengan menjumlahkan panjang bambu pertama dan bambu kedua yaitu $384 \mathrm{~cm}$ ditambah 128 $\mathrm{cm}$ sehingga diperoleh hasil $512 \mathrm{~cm}$. Setelah melakukan wawancara dengan siswa, siswa belum paham maksud soal nomor 4. Siswa hanya mencoba-coba untuk menghitung dengan melakukan penjumlahan. 


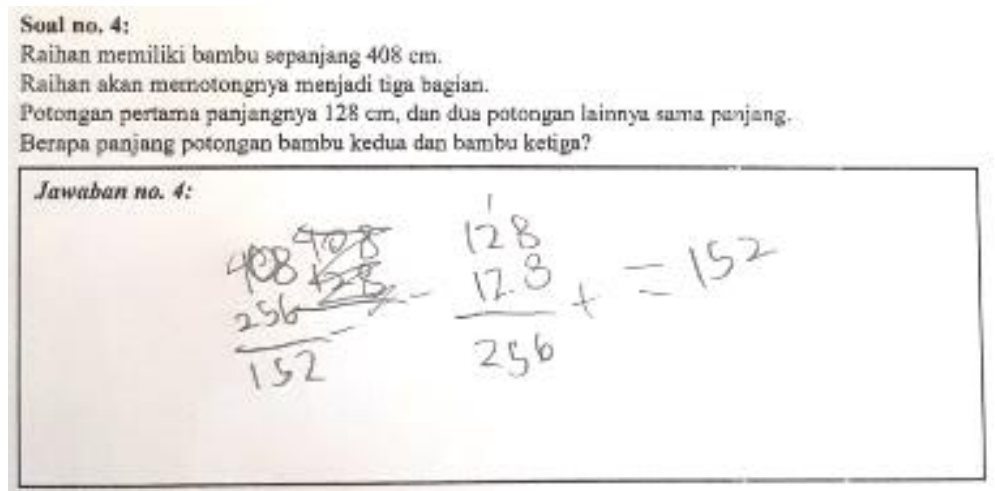

Gambar 17. Jawaban Tipe E Nomor 4

Gambar 17 merupakan jawaban siswa yang kurang tepat. Setelah melakukan wawancara terhadap siswa, siswa mengira bahwa bambu yang memiliki ukuran sama adalah bambu pertama dan bambu kedua yaitu $128 \mathrm{~cm}$, sehingga panjang kedua bambu adalah 256 $\mathrm{cm}$. Selanjutnya siswa mengurangkan panjang bambu mula-mula dengan panjang bambu pertama dan kedua, atau hasil dari $408 \mathrm{~cm}$ dikurangi $256 \mathrm{~cm}$ yaitu $152 \mathrm{~cm}$.

\section{PEMBAHASAN}

Berdasarkan analisis data, diperoleh gambaran mengenai literasi numerasi yang dianalisis berdasarkan learning trajectory siswa dalam menyelesaikan soal pemecahan masalah tidak terstruktur. Secara umum, siswa memiliki kemampuan mengaplikasikan konsep bilangan dan keterampilan operasi hitung di dalam kehidupan sehari-hari. Kemampuan ini ditunjukkan dengan kecakapan siswa dalam menggunakan keterampilan matematika dalam memecahkan masalah tidak terstruktur pada materi bilangan. Numerasi dapat diartikan sebagai kemampuan untuk mengaplikasikan konsep bilangan dan keterampilan matematika dalam kehidupan sehari-hari, kenyamanan terhadap bilangan dan cakap menggunakan matematika secara praktis, dan memiliki apresiasi dan pemahaman informasi yang dinyatakan secara matematika (Kemdikbud, 2017). Hal tersebut didukung dengan beberapa penjelasan siswa mengenai learning trajectory dan strategi yang digunakan siswa yang dipaparkan melalui proses wawancara.

Prinsip dasar literasi numerasi adalah bersifat kontekstual. Dengan demikian, soal yang dibuat untuk mengeksplorasi literasi numerasi siswa haruslah yang berkaitan dengan kehidupan sehari-hari siswa melalui soal cerita. Integrasikan operasi aritmatika dasar ke dalam bentuk soal cerita juga bertujuan agar siswa lebih memahami konsep penggunaan operasi 
aritmatika. Melalui soal cerita, anak tidak hanya belajar melatih kemampuan literasi numerasinya akan tetapi belajar melatih literasi dasar berupa membaca pemahaman. Hal ini dikarenakan kemampuan siswa dalam berpikir analitis serta pemecahan masalah secara tidak langsung berkorelasi dengan kemampuan membaca pemahaman anak (Holmes \& Dowker, 2013).

Soal cerita yang diberikan dalam penelitian ini adalah soal pemecahan masalah tidak terstruktur yang berkaitan dengan bilangan. Hasil penelitian menunjukkan bahwa beberapa siswa mampu memecahkan masalah tidak terstruktur dalam kehidupan sehari-hari. Hal ini dapat ditunjukkan melalui pekerjaan siswa. Beberapa pekerjaan siswa menunjukkan bahwa beberapa siswa mampu menyelesaikan soal dengan berurut. Hasil tersebut juga dikomunikasikan oleh siswa secara tertulis lengkap beserta penjelasannya.

Selanjutnya, beberapa siswa mampu menganalisis informasi yang diperoleh dari soal kemudian menggunakan interpretasi analisis untuk memprediksi dan mengambil kesimpulan. Kesimpulan ini merupakan bagian terpenting dari pekerjaan siswa. Beberapa siswa mampu menyelesaikan soal dengan baik, namun tidak dapat menyimpulkan penyelesaian masalah. Siswa yang mampu membuat kesimpulan itulah yang memiliki kemampuan literasi numerasi yang baik.

Analisis selanjutnya dilakukan untuk mengetahui kesulitan yang dialami siswa dalam memecahkan masalah tidak terstruktur pada materi bilangan. Analisis dilakukan terhadap pekerjaan siswa yang salah. Beberapa tipe kesalahan yang dilakukan oleh siswa diantaranya: (a) salah dalam menginterpretasikan maksud soal; (b) salah ketika melakukan operasi hitung; dan (c) salah dalam mengambil kesimpulan. Berdasarkan hasil wawancara diperoleh alasan kesalahan yang dilakukan oleh siswa, yakni siswa memiliki beberapa kesulitan.

Pertama, kesulitan yang dialami siswa yaitu memahami soal dari segi kemampuan membaca pemahaman dan kalimat matematika. Dengan demikian, kesulitan siswa dalam memecahkan soal cerita matematika tidak cukup didekati dengan pandangan ilmu matematika, tetapi memungkinkan dengan pandangan baru, yakni soal cerita sebagai sebuah wacana yang berkaitan dengan ilmu bahasa (Sumarwati, 2013). Jika anak pada usia sekolah permulaan tidak segera memiliki kemampuan membaca, maka ia akan mengalami banyak kesulitan dalam mempelajari bidang studi pada kelas berikutnya (Abdurrahman, 2012). 
Kesulitan kedua adalah kurangnya pemahaman siswa pada materi prasyarat. Pemahaman siswa terhadap materi prasyarat menjadi penentu siswa dalam menyelesaikan soal. Hasil wawancara menunjukkan bahwa siswa belum memahami konsep waktu, yakni bahwa terdapat tujuh hari dalam seminggu. Konsep waktu merupakan materi yang berkaitan dengan masalah. Padahal konsep waktu telah dipelajari oleh siswa pada jenjang sebelumnya.

Kesulitan ketiga yaitu kesulitan siswa dalam membangun strategi penyelesaian masalah. Jika merujuk pada langkah penyelesaian masalah menurut Polya (1957) terdapat empat tahap penyelesaian yaitu: (a) memahami masalah; (b) merencanakan penyelesaian masalah; (c) melaksanakan rencana penyelesaian masalah; dan (d) pemeriksaan kembali. Siswa tersebut sudah dapat memahami masalah, namun ia keliru ketika menyusun penyelesaian masalah.

Kesulitan selanjutnya yaitu kesulitan dalam mengambil kesimpulan. Beberapa siswa meiliki kemampuan matematis yang baik, dapat memecahkan masalah matematis dengan baik, namun belum mampu membuat kesimpulan dari pemecahan masalah. Hal ini menunjukkan bahwa kemampuan numerasi siswa belum berkembang dengan baik.

Hasil penelitian ini melengkapi hasil penelitian yang dilakukan oleh Suganda (2014) bahwa kesulitan yang dialami siswa dalam menyelesaikan soal pemecahan masalah diduga berawal dari memahami masalah, merepresentasikan masalah ke dalam bentuk matematika maupun gambar dari suatu masalah, membangun penalaran dalam menyelesaikan soal pemecahan masalah, dan membangun strategi penyelesaian. Literasi numerasi mencakup keterampilan mengaplikasikan konsep dan kaidah matematika dalam situasi real sehari-hari, saat permasalahannya sering kali tidak terstruktur, memiliki banyak cara penyelesaian, atau bahkan tidak ada penyelesaian yang tuntas, serta berhubungan dengan faktor nonmatematis.

\section{KESIMPULAN}

Kemampuan numerasi anak akan memengaruhi learning trajectory nya. Berdasarkan analisis learning trajectory, dapat disimpulkan bahwa literasi numerasi siswa kelas 4 dalam pemecahan masalah tidak terstruktur pada materi bilangan yaitu: siswa mampu memecahkan masalah tidak terstruktur dalam konteks kehidupan sehari-hari; siswa mampu menganalisis informasi yang diperoleh dari soal kemudian menggunakan interpretasi analisis untuk memprediksi dan mengambil kesimpulan. Kesulitan yang dialami siswa dalam menyelesaikan 
masalah tidak terstruktur dalam materi bilangan yaitu: kesulitan memahami soal dari segi kemampuan membaca pemahaman dan kalimat matematika; kurangnya pemahaman siswa pada materi prasyarat; Kesulitan membangun strategi penyelesaian; dan kesulitan dalam mengambil kesimpulan.

\section{REKOMENDASI}

Sebagai upaya untuk mengatasi kesulitan belajar yang dialami siswa dalam penyelesaian masalah tidak terstruktur dalam materi bilangan, guru perlu mengidentifikasi letak kesulitan pada siswa. Selanjutnya, dapat diterapkan strategi act it out (memerankan masalah) dan make a drawing or diagram (membuat gambar atau diagram). Untuk memiliki kemampuan literasi numerasi yang baik, siswa harus mampu berpikir dan berkomunikasi secara kuantitatif, untuk memahami data, memiliki kesadaran spasial, untuk memahami pola dan urutan, dan untuk mengenali situasi di mana penalaran matematika dapat diterapkan untuk memecahkan masalah. Selain itu, bimbingan lebih lanjut dengan berbagai strategi dimulai dari strategi yang melibatkan benda konkret sampai abstrak sangat diperlukan.

\section{REFERENSI}

Abdurrahman, M. (2012). Anak Berkesulitan Belajar: Teori, Diagnosis, dan Remediasinya. Jakarta: Rineka Cipta.

Alberta. (2018). Literacy and Numeracy Progressions. (Online), (https://education.alberta.ca/literacy-and-numeracy/), diakses 27 Agustus 2018.

Clements, D. H., \& Sarama, J. (2004). Learning Trajectories in Mathematics Education. Mathematical Thinking and Learning, 6(2), 81-89. doi:10.1207/s15327833mt10602_1.

Creswell, J.W. (2013). Research design: Pendekatan kualitatif, kuantitatif, dan mixed. Yogyakarta: Pustaka Pelajar.

Creswell, J. W. (2014). Penelitian Kualitatif dan Desain Riset. Yogyakarta: Pustaka Pelajar.

Goel, V. (1992). A Comparison of Well-Structured and Ill-Structured Task Environments and Problem Spaces. Proceedings of the Fourteenth Annual Conference of the Cognitive Science Society. Hillside, NJ: Erlbaum. 
Holmes, W., \& Dowker, A. (2013). Catch Up Numeracy: A Targeted Intervention for Children Who are Low-Attaining in Mathematics. Research in Mathematics Education, 15(3), 249-265.

Jordan, N. C., Kaplan, D., Ramineni, C., \& Locuniak, M. N. (2009). Early Math Matters: Kindergarten Number Competence and Later Mathematics Outcomes. Developmental psychology, 45(3), 850-867.

Kementerian Pendidikan dan Kebudayaan. (2017). Gerakan Literasi Nasional. (Online), (http://gln.kemdikbud.go.id).

Light, J. G., \& DeFries, J. C. (1995). Comorbidity of Reading and Mathematics Disabilities: Genetic and Environmental Etiologies. Journal of Learning Disabilities, 28, 96-106.

Margono, S. (2014). Metode Penelitian Pendidikan. Jakarta: Rineka Cipta.

Munn, P. (1994). The Early Development of Literacy and Numeracy Skills. European Early Childhood Education Research Journal, 2, 5-18.

Naughton, G. M \& Hughes, P. (2009). Doing Action Research in Early Childhood Studies: A Step by Step Guide. USA: Open University Press.

Polya. (1957) How to Solve It. (Online), (http://math.hawaii.edu/home/pdf/putnam/PolyaHowToSolveIt.pdf).

Purpura, D. J. (2009). Informal Number-Related Mathematics Skills: An Examination of The Structure of and Relations Between These Skills in Preschool. Unpublished dissertation, Florida State University.

Purpura, D. J., Hume, L. E., Sims, D. M., \& Lonigan, C. J. (2011). Early Literacy and Early Numeracy: The Value of Including Early Literacy Skills in The Prediction of Numeracy Development. Journal of Experimental Child Psychology, 110, 647-658. 
Purpura, D. J., Baroody, A. J., \& Lonigan, C. J. (2013). The Transition from Informal to Formal Mathematical Knowledge: Mediation by Numeral Knowledge. Journal of Educational Psychology, 105, hlm. 453-464.

Putra, N. \& Dwilestari, N. (2012). Penelitian Kualitatif PAUD Pendidikan Anak Usia Dini. Jakarta: Raja Grafindo Persada.

Sarama, J., \& Clements, D. H. (2009). Early Childhood Mathematics Education Research: Learning Trajectories for Young Children. New York, NY: Routledge.

Suganda, V. A. (2014). Analisis Kesulitan dalam Menyelesaikan Soal Pemecahan Masalah dan Sikap Matematis Siswa Kelas V Sekolah Dasar. Tesis. Bandung: Universitas Pendidikan Indonesia.

Sumarwati. (2013). Soal Cerita Dengan Bahasa Komunikatif untuk Meningkatkan Kualitas Pembelajaran Matematika Sekolah Dasar. Jurnal Ilmu Pendidikan, 1(19).

Toy, S. (2007). Online Ill-Structured Problem-Solving Strategies and Their Influence on Problem-Solving Performance. Retrospective Theses and Dissertations. 15916. http://lib.dr.iastate.edu/rtd/15916. 